\title{
IMPLEMENTASI PEMBELAJARAN TEORI BILANGAN DALAM MATEMATIKA UNTUK MEMILIH PEMIMPIN BANGSA YANG HANDAL
}

\author{
Suparyana \\ Pengawas Sekolah SMA Disdikpora Kabupaten Gunungkidul \\ E-mail: suparyanamatematika@gmail.com
}

\begin{abstract}
ABSTRAK
Untuk memilih seorang pemimpin bangsa yang handal diperlukan suatu cara yang cerdas dan cermat. Salah satu cara yang dapat digunakan adalah dengan mengimplementasikan pembelajaran teori bilangan dalam matematika. Tujuan dari penulisan artikel ini adalah menginspirasi pembaca dalam memilih seorang pemimpin yang handal dengan cara mengimplementasikan teori bilangan dalam matematika. Dalam teori bilangan angka dan bilangan seringkali dianggap sebagai dua entitas yang sama, pada hal secara baku angka dan bilangan merupakan dua entitas yang berbeda, namun memiliki hubugan yang sangat erat. Angka adalah sesuatu yang digunakan untuk melambangkan bilangan, sedangkan bilangan merupakan suatu konsep matematika yang digunakan untuk pencacahan dan pengukuran.Metode yang digunakan dalam artikel ini adalah bilangan bulat dalam teori bilangan, yakni memandang keistimewaan letak suatu bilangan bulat. Bilangan bulat terdiri atas bilangan positif, bilangan nol, dan bilangan negatif dan dilambangkan dengan $B=\{\ldots,-3,-2,-1,0,1,2,3, \ldots$ \}. Sedangkan nol, jika tidak ditemukan angka nol tulisan satu juta dalam bilangan romawi ditulis apa? Bisa-bisa selembar kertas tidak cukup untuk menuliskan symbol satu juta. Nol adalah perangkat paling penting dalam matematika.

Adapun hasil yang hendak dicapai dalam tulisan ini adalah memberi pelajaran bagi kita, yakni dalam mencalonkan diri sebagai seorang pemimpin hendaknya terlebih dahulu bercermin terhadap kompetensi kepemimpinan yang dimiliki. Selain itu memberi pelajaran bagi kita, yakni seorang calon pemimpin yang mempunyai nol kompetensi kepemimpinan, menyadari akan keberadannya. Maka dari itu seorang pemilih harus cerdas dan cermat, yakni dengan mengimplementasikan teori bilangan di atas agar mendapatkan calon pemimpin yang handal.
\end{abstract}

Kata Kunci : Letak Bilangan Bulat, Pemimpin Yang Handal

\section{ABSTRACT}

To choose a reliable leader of the nation required an intelligent and careful manner. One way that can be used is to implement learning number theory in mathematics. The purpose of writing this article is to inspire the reader in choosing a reliable leader by implementing number theory in mathematics. In number theory of numbers and numbers are often regarded as the two entities are the same, in terms of raw numbers and as numbers are two different entities, but have very close ties. Figures is something that is used to symbolize the number, while the number is a mathematical concept that is used for the enumeration and measurement. The method used in this article is an integer in number theory, which looked at the location of an integer privilege. Integer consists of positive numbers, zero, and negative numbers and is denoted by $\mathrm{B}=\{\ldots,-3,-2,-1,0,1,2,3, \ldots\}$ While zero, if not zero posts found one million in roman numbers written what? I could have a piece of paper is not enough to write the symbol of one million. Zero is the most important device in mathematics.

As for the results to be achieved in this paper is a lesson for us, namely in the running for a leader should first reflect on leadership competencies possessed. Besides giving a lesson for us, that a prospective leader has zero leadership competencies, aware of its existence. Therefore a voter have to be smart and careful, by implementing the above number theory in order to obtain a reliable future leaders.

Keywords: Location of Integer, Leader Reliable 


\section{Pendahuluan}

Apabila kita menyimak dengan seksama berita yang terjadi akhir-akhir ini, baik melalui media cetak maupun elektronik, setiap pemilihan seorang pemimpin berakhir dengan keributan dan kericuhan.

Pengalaman sejarah dapat kita lihat, Ricuh Pilkada Jelang pemilihan kepala daerah langsung, beberapa daerah di Indonesia diwarnai demo bahkan tak jarang berakhir dengan bentrokan antar masa pendukung.

Ada lagi yang memperkeruh situasi politik dalam negeri partai-partai yang notabennya kalah dalam pemilu sekarang bersatu untuk menyalahkan pemerintah, mereka menilai pemilu 2009 ini di design untuk memenangkan partai pendukung pemerintah. (Kisruh Pemilu 2009, Posted by ferniawan rese at 10:53 AM . 16 April 2009 Labels: news )

Berbagai kericuhan Pilkada terjadi di berbagai daerah. Di Maluku Utara, Depok, Sulawesi Selatan, Pematang Siantar, Manggarai NTT Pilkada berakhir dengan keributan. Ini semua disebabkan Penguasa yang seharusnya menerima hasil pilkada apa adanya ternyata hanya menginginkan kemenangan pasangannya. Akibatnya seluruh tata aturan dilabrak demi mengesahkan kemenangan yang ditargetkan.

\section{(Sistem TI Pilkada untuk Mencegah}

Keributan Pilkada, Posted on Januari 25, 2008 by A Nizami )

Sengketa atau perselisihan hasil pemilihan umum kepala daerah (pemilukada) sebagaimana yang terjadi dalam praktik pemilukada di Indonesia, pada dasarnya merupakan sengketa hukum (rechtsstrijd). Secara teoretikal, sengketa hukum (rechtsstrijd) sekaligus pula merupakan sengketa kepentingan (belangenstrijd).

(Penyelesaian

Perselisihan Hasil Pemilukada dalam Hukum Acara Pemilukada di Indonesia, Oleh : Widodo Ekatjahjana, 2009)

Kepemimpinan adalah seni dan ilmu untuk mempengaruhi orang lain dalam mencapai tujuan tertentu, dengan cara tertentu sehingga orang lain mengikutinya. (Herminanto Sufyan, 1998)

Kepemimpinan sekolah adalah cara atau usaha kepala sekolah dalam mempengaruhi, mendorong, membimbing, mengarahkan, dan menggerakkan pihak yang terkait, untuk bekerja/berperan serta guna mencapai tujuan yang telah ditetapkan. (Zamroni, 2000)

Kepemimpinan yang efektif adalah seorang pemimpin yang berhasil dalam membimbing, mengarahkan dan memimpin seseorang atau sekelompok orang yang bertindak, berpendapat, atau mencapai suatu tujuan. (Vincent P. Costa, 2000) 
Berdasarkan beberapa pendapat di atas, dapat diperoleh pengertian, bahwa untuk memilih seorang pemimpin apabila hanya mengedepankan uang ataupun kerabat dekat pejabat yang berkuasa saat itu dan mengesampingkan kompetensi yang dimiliki calon pemimpin, maka akan terpilihlah pemimpin yang kurang professional. Apabila calon terpilih tersebut kurang professional, mana mungkin mereka dapat mempengaruhi, mendorong, membimbing, mengarahkan, menggerakkan, stafnya untuk bekerja dalam rangka mencapai tujuan yang telah ditetapkan. Kata bijak mengatakan “ apabila suatu urusan diserahkan kepada yang bukan ahlinya maka tunggulah saat kehancuran".

Tentunya kita tidak rela apabila negara tercinta ini hancur disebabkan dipimpin oleh seseorang yang tidak berkompenten tentang ketatanegaraan. Demikian juga kita tidak rela apabila pendidikan di negara tercinta ini hancur disebabkan oleh pembuat kebijakan pendidikan yang kurang berkompenten terhadap pendidikan.

Dengan berdasarkan uraian di atas, rumusan masalah dalam karya tulis ini adalah " Bagaimana strategi yang harus ditempuh untuk memilih seorang pemimpin yang handal dengan mengimplementasikan pembelajaran Teori Bilangan dalam Matematika?

\section{Metode Penelitian}

Apabila kita mengamati letak suatu bilangan maka akan diperoleh nilai lebih besar atau lebih kecil . Kapan akan diperoleh nilai lebih besar dan kapan diperoleh nilai lebih kecil, serta apa penyebab nilai lebih besar / lebih kecil tersebut ? Contoh : Angka 3 dan 7, dua angka ini kita susun dalam suatu bilangan akan mempunyai nilai lebih besar jika 7 terletak di depan dan 3 di belakang yakni 73, dan akan mempunyai nilai lebih kecil jika 3 terletak di depan dan 7 di belakang yakni 37. Maknanya, seseorang yang mempunyai kompetensi kepemimpinan lebih banyak sebaiknya menempatkan diri di depan dan sebaliknya. Adapun Kompetensi kepemimpinan yang hendaknya dimiliki antara lain

\section{Integritas kepada orang lain}

Integritas atau memberikan kesetiaan atau kepedulian kepada orang lain atau bawahan, berarti mempertahankan nilai-nilai dan moral yang dipercayai kepada orang lain.

\section{Memelihara orang lain}

Jika melihat kehidupan disekeliling kita, akan ditemui seseorang yang sangat membutuhkan makan, aman dan harapan. Sebagai seorang pemimpin hendaknya menaruh perhatian yang tulus kepada orang yang dipimpin agar memperoleh rasa aman 
dan nyaman, tentunya dengan cara yang mendidik.

\section{Percaya terhadap kemampuan orang} lain

Setiap orang akan merasa senang jika mereka dipercaya. Berilah kepercayaan kepada orang yang kita pimpin sesuai dengan kemampuan dan wilayah kerjanya..

4. Mendengar apa yang disampaikan orang lain

Dengarkan dan perhatikan apa yang di sampaikan orang lain, sebab hal ini sesungguhnya kita sudah membangun hubungan terhadap orang lain dan mereka akan merasa dihargai.

\section{Kemampuan memahami orang lain}

Setiap orang sebenarnya ingin didengar, dihormati dan dipahami. Apabila hal ini dilakukan oleh pemimpin maka mereka akan merasa dimotivasi dan dipengaruhi secara positif.

\section{Mengembangkan bakat orang lain}

Apabila hal ini dilakukan seorang pemimpin berarti sudah membantu mereka menangkap peluang untuk mewujudkan potensi mereka. Berikan kesempatan kepada orang yang kita pimpin agar mereka bisa terus maju dan meraih jenjang yang lebih tinggi.

7. Menjadi arah (navigator) bagi orang lain
Ketika seseorang memiliki potensi pribadinya maka ia memerlukan arah untuk mengembangkan potensi tersebut. Dengan mengarahkan orang lain kepada kesuksesan, tanpa disadari kita telah melatih diri untuk menjadi pribadi yang lebih sukses.

\section{Berkomunikasi dengan orang lain}

Gerbong itu berada di atas rel, dimuati barang-barang, mempunyai tujuan dan rute. Gerbong ini tidak memiliki arah jika tidak dihubungkan dengan lokomotif. Hal ini sama dengan ketika kita membawa orang pergi, kemana mereka harus pergi, dimana keberadaannya, ini hanya akan diketahui jika kita memiliki hubungan dengan banyak pihak, (maksudnya seorang pemimpin harus mempunyai arah dan tujuan yang jelas.

\section{Memperlengkapi orang lain}

Ketika memberi wewenang kepada orang lain maka berarti telah meningkatkan kemampuan orang lain tanpa menurunkan kemampuan yang dimiliki. Bawahannya semakin pintar, pada akhirnya tujuan bersama pun tercapai dengan hasil terbaik.

10. Memproduksi orang berpengaruh

Hal ini berarti kita telah melahirkan generasi penerus yang mampu menciptakan orang-orang berpengaruh. Dengan demikian semua personil, elemen dan pihak memiliki kemampuan 
seperti yang diharapkan dan melakukan seperti apa yang diinginkan tanpa harus selalu diperintah. (Rabu, 08 Juli 2009, http://aryscouters.blogspot.com.2009, Sepuluh Kreteria Pemimpin Yang Baik) Adapun ciri-ciri seorang pemimpin yang handal antara lain :

Pertama,

Harus dengan cepat memahami kebutuhan orang-orang yang dipimpinnya dan berusaha untuk memenuhinya.

Kedua,

Harus memiliki kemampuan untuk membuat orang lain sukses.

Ketiga,

Harus selalu memiliki semangat untuk mempelopori dan selalu bergerak maju.

Keempat,

Harus menginvestasikan semua usaha kita untuk pengembangan diri. (www.henlia.com.2006/Internet)

\section{Hasil dan Pembahasan}

Artikel ini berjudul "Implementasi Pembelajaran Teori Bilangan dalam Matematika untuk Memilih Pemimpin Bangsa Yang Handal“"

Artikel ini menggunakan strategi pemecahan masalah matematika, yakni letak suatu angka dalam bilangan dan langkah-langkah penyelesaian soal matematika. Hasil yang ingin dicapai adalah seorang calon pemimpin sebelum mendaftarkan ke panitia pemilihan hendaknya instrupeksi diri, dan menyadari tentang keberadaan kompetensi kepemimpinan yang dimiliki sehingga timbul budaya malu. Konteks malu disini dalam hal yang positif, yakni malu apabila tidak dapat memimpin, malu apabila ada yang lebih mampu, malu apabila tidak dapat mengerjakan amanah yang dibebankan.

\section{Pembahasan}

Dalam matematika dikenal bilangan Bulat : $0, \pm 1, \pm 2, \pm 3, \pm 4, \pm 5, \pm 6$, $\pm 7, \pm 8$, dan $\pm 9, \ldots$ Bilangan tersebut mempunyai sifat: $0<1<2<3<4<5<$ $6<7<8<9<\ldots$ (< : dibaca lebih kecil dari).

Atau : $0>-1>-2>-3>-4>-5>-$ $6>-7>-8>-9>\ldots$ (> : dibaca lebih besar dari).

Dari bilangan tersebut apabila disusun mempunyai sifat : $9876543210>$ $9876543201>9876543021>9876540321$ $>9876504321>9876054321>$ $9870654321>9807654321>9087654321$ $>0987654321>\ldots$

Bilangan pada susunan di atas, 9876543210 merupakan bilangan terbesar sebab 0 terletak paling belakang, dan sebaliknya 0987654321 merupakan bilangan terkecil sebab 0 terletak paling depan. Makna dari 0 adalah seseorang 
yang tidak mempunyai kompetensi kepemimpinan kebetulan terpilih menjadi pemimpin karena uangnya banyak ataupun masih keluarga dekat pejabat maka hasil kepemimpinannya dipertanyakan.

Renstra Pendidikan Nasional 2005-2009 adalah terwujudnya sistem pendidikan sebagai pranata sosial yang kuat dan berwibawa untuk memberdayakan semua warga Indonesia berkembang menjadi manusia yang berkualitas, sehingga mampu dan proaktif menjawab tantangan zaman yang selalu berubah. (Bambang Sudibyo, 2007).

Apabila renstra di atas kita kaitkan dengan fakta di lapangan sangat bertentangan, yakni dalam hal pemilihan seorang pemimpin yang dilaksanakan dengan tidak jujur dan tidak transparan akan mendapatkan pemimpin yang tidak berkualitas, sehingga mana mungkin dapat memberdayakan warga negara yang berkualitas yang dapat menjawab tantangan zaman yang selalu berubah. Dengan demikian tidak dapat ditawar lagi, untuk mendapatkan pemimpin yang berkualitas harus sesuai dengan kompetensi yang dimiliki.

\section{Kendala-kendala yang dihadapi}

Dalam masyarakat kadang-kadang dalam memilih seorang pemimpin dicampuri unsur politik, yakni memilih calon yang memberi amplop tebal ataupun calon kerabat dekat pejabat. Sehingga boleh jadi calon dari keluarga kurang mampu tetapi mempunyai kompetensi kepemimpinan yang bagus akan tersisih. Selain itu kadang-kadang dalam memilih seorang pemimpin hanya ikut-ikutan tidak sesuai dengan hati nurani, disebabkan takut dengan adanya teror/ancaman.

Dalam matematika dikenal bilangan negatif : $0,-1,-2,-3,-4,-5,-6,-7$, -8 , dan -9 . Bilangan tersebut mempunyai sifat $0>-1>-2>-3>-4>-5>-6>--7>$ $-8>-9$. (> : dibaca lebih besar dari). Dari bilangan tersebut apabila disusun mempunyai sifat : $-9876543210<-$ $9876543201<-9876543021<-9876540321$ $<-9876504321<-9876054321<-$ $9870654321<-9807654321<-9087654321$ $<-0987654321<\ldots$

Bilangan pada susunan di atas, 9876543210 merupakan bilangan terkecil sebab di depan bilangan ada tanda negatif $(-)$ dan sebaliknya -0987654321 merupakan bilangan terbesar sebab di depan bilangan ada tanda negatif (-). Makna dari negatif (-) adalah seseorang yang mempunyai karakter yang kurang baik di masyarakat, seperti "Mo Limo" artinya : Madat /pecandu narkoba - Madon /suka main perempuan/pria (?) - Minum /suka mabuk2-an - Main/berjudi/bertaruh - Maling/ mengambil yang bukan haknya.)

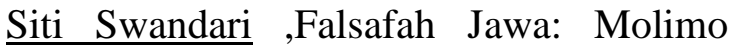
(M.5). 
Apabila seseorang kebetulan terpilih menjadi pemimpin karena ancamannya terhadap masyarakat maka kepemimpinannya kurang profesional.

Hal-hal yang hendaknya dihindari oleh seorang pemimpin antara lain,

1. Arogansi

Hal ini terjadi ketika si pemimpin merasa dirinya lebih tinggi, lebih hebat dan lebih berkuasa dari pada orang lain. Ia mulai dihinggapi "invincible and infallible syndrome" (sindrom merasa diri tak terkalahkan dan tak pernah salah).

2. Mendengarkan nasehat buruk.

Seorang pemimpin perlu mendengar nasehat dari orang lain. Adapun penasehat ada 2 jenis.

Pertama, penasehat yang bijak, yaitu penasehat yang akan memberi hal-hal yang amat berguna bagi si pemimpin.

Kedua, penasehat yang buruk, yaitu penasehat yang akan mejerumuskan sang pemimpin dalam kesulitan besar.

Dengan demikian merupakan tantangan bagi seorang pemimpin untuk dapat memilih penasehat yang bijak.

3. Kurangnya Integritas

Yang dimaksud integritas adalah adanya satu kata dan perbuatan. Integritas merupakan magnet paling kuat untuk mempengaruhi orangorang yang berada dalam suatu kepemimpinan.

4. Berusaha melakukan semua hal

Ketika seorang pemimpin berusaha melakukan semua hal seorang diri, sudah pasti dia kan gagal menjadi pemimpin. Seorang pemimpin harus "berani" medelegasikan, hal-hal kecil dan sepele kepada orang lain.

5. Menghindar dari tanggung jawab.

Ketika seorang pemimpin menolak atau menghindar melakukan sesuatu yang menjadi tanggung jawabnya, maka bisa dipastikan, cepat atau lambat ia akan kehilangan dukungan dari mereka yang dipimpinnya.

6. Tidak mampu membangun nilai yang kuat

Dalam buku "Tribal Leadership" nilai adalah sesuatu yang harus dihargai dan dijunjung tinggi dalam suatu organisasi. Dengan demikian seorang pemimpin yang gagal membangun nilai yang kuat bagi organisasi yang dipimpinnya, maka organisasi itu tidak akan berjalan dengan baik.

7. Percaya buta

Seorang pemimpin yang baik tidak boleh percaya buta kepada orang lain yang belum diketahui status 
integritas dan kompetensinya. Supervisi tetap diperlukan, sebab dengan disupervisi seseorang merasa dihargai, diperhatikan atas apa yang dilakukannya.

Apabila hal seperti ini berlangsung terus-menerus, kapan negara kita menemukan pemimpin yang handal yang akan membawa kesejahteraan, kemakmuran, kemajuan rakyatnya?

Maka dari itu mulai saat ini juga dan mulai dari diri kita, jika memilih seorang pemimpin hendaknya yang terbaik, berkualitas, terbebas dari unsur-unsur politik, sehingga jangan sampai tergiur dengan stimulan sesaat yang akan mengorbankan orang banyak.

\section{Faktor-faktor Pendukung}

Di dalam matematika kita mengenal nol (0) . Bilangan nol (0) dapat diibaratkan seseorang yang mempunyai 0 kompetensi kepemimpinan. Bilangan 0 apabila dilihat secara sekilas tidak mempunyai nilai, namun apabila diperhatikan secara seksama mempunyai makna yang sangat berarti. Sedangkan sembilan (9) dapat diibaratkan seseorang yang mempunyai kompetensi kepemimpinan tinggi.

Dalam matematika 09 bernilai sembilan, sedangkan 90 bernilai sembilan puluh, 009 bernilai sembilan sedangkan 900 bernilai sembilan ratus, 0000009 bernilai sembilan, sedangkan 9000000 bernilai sembilan juta, dan seterusnya.

Dari uraian di atas dapat kita fahami bahwa, bilangan nol (0) akan lebih bermakna apabila letaknya di belakang, sedangkan 9 akan lebih bermakna apabila letaknya di depan. Seperti halnya dalam suatu organisasi, seseorang yang tidak mempunyai kompetensi kepemimpinan dengan ikhlas memposisikan diri di belakang sebagai anggota/staf dan tidak akan ambisius memposisikan di depan (sebagai pemimpin). Sebaliknya seseorang yang mempunyai kompetensi kepemimpian tinggi dengan ikhlas memposisikan di depan mengemban amanah dari anggota. Namun demikian seorang yang diberi amanah sebagai pemimpin jangan sekali-kali meremehkan staf/anggota yang dipimpinnya, seperti halnya bilangan nol (0), semakin banyak nol (0) di belakang semakin besar nilainya.

\section{Alternatif Solusi}

Dalam memilih seorang pemimpin tentunya kita sepakat memilih calon yang terbaik, berkualitas, mempunyai kompetensi kepemimpinan atau dengan kata lain memilih pemimpin yang handal. Untuk memperoleh pemimpin yang handal diperlukan kejujuran, keterbukaan (transparan), akuntabel sehingga hasil pemilihan diterima semua pihak. 
Untuk keperluan itu semua, sebaiknya sebelum pemilihan dimulai, membuat Pakta Integritas yang isinya antara lain :

a. setiap calon beserta pendukungnya saling menghormati;

b. setiap calon beserta pendukungnya menerima sepenuhnya hasil pemilihan secara ikhlas;

c. setiap calon beserta pendukungnya siap menjaga keamanan dan tidak akan melakukan tindakan anarchis;

d. setiap calon beserta pendukungnya mentaati tata-tertib yang berlaku;

e. setiap calon beserta pendukungnya siap menerima sanksi apabila melanggar Pakta Integritas ini. Berkaitan dengan hal ini, untuk mengantisipasi kesuksesan pemilu 2014 di Yogyakarta, Ketua Bawaslu DIY. mengajak kepada seluruh elemen masarakat untuk membantu Bawaslu, dengan "Gerakan Satu Juta Relawan Pengawas Pemilu. Mudah-mudahan dengan mengimplementasikan pembelajaran Teori Bilangan dalam Matematika untuk memilih seorang pemimpin ,akan memperoleh pemimpin yang handal, yakni pemimpin yang dapat "ngayomi dan ngayemi " rakyat di wilayah yang dipimpinnya sehingga dapat bekerja dengan senang, damai, sejahtera, yang pada akhirnya dapat meningkatkan kinerja semua pihak dan dapat membawa kemajuan di segala bidang seperti yang kita cita-citakan bersama.

\section{Kesimpulan}

Dari uraian di atas, kami dapat menyimpulkan hal-hal sebagai berikut:

1. Seorang pemimpin adalah merupakan panutan orang yang dipimpin, sehingga dalam memilih pemimpin lebih mengedepankan kompetensi kepemimpinan dari pada uang dan kerabat dekat pejabat.

2. Dalam kehidupan sehari-hari hendaknya seorang pemimpin dapat mawas diri dan menempatkan diri sebagaimana letak angka-angka dalam suatu bilangan.

3. Seorang pemimpin adalah pengemban amanah maka dalam menjalankan tugas dengan penuh kesungguhan dan tanggung jawab.

4. Seorang pemimpin hendaknya selalu mempunyai keyakinan bahwa setiap stafnya mempunyai kemampuan (potensi), sehingga terhadap stafnya tidak bertindak sewenang-wenang, seperti halnya bilangan nol meskipun ketika berada di depan kurang bermakna namun apabila menempatkan di belakang sangat bermakna.

Setelah membaca artikel ini diharapkan dapat memberi inspirasi pembaca dalam memilih pemimpin yang handal, mulai dari pemimpin tingkat 
daerah sampai pusat, sebagaimana yakni mengubah paradigma lama menuju paradigma baru dalam tabel berikut.

Tabel 1. Perubahan Paradigma

\begin{tabular}{|c|c|}
\hline Paradigma Lama & Paradigma Baru \\
\hline 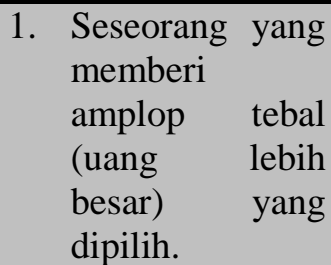 & $\begin{array}{l}\text { 1. Seseorang yang } \\
\text { mempunyai } \\
\text { kompetensi } \\
\text { kepemimpinan } \\
\text { tertinggi yang } \\
\text { dipilih. }\end{array}$ \\
\hline $\begin{array}{l}\text { 2. Seseorang yang } \\
\text { masih kerabat } \\
\text { dekat pejabat } \\
\text { yang } \\
\text { diutamakan. }\end{array}$ & $\begin{array}{l}\text { 2. Seseorang yang } \\
\text { mempunyai } \\
\text { keahlian } \\
\text { kepemimpinan }\end{array}$ \\
\hline $\begin{array}{l}\text { 3. Kesejahteraan } \\
\text { hanya dinikmati } \\
\text { oleh orang- } \\
\text { orang tertentu. }\end{array}$ & $\begin{array}{l}\text { 3. Kesejahteraan } \\
\text { dinikmati oleh } \\
\text { semua pihak } \\
\text { yang terkait. }\end{array}$ \\
\hline $\begin{array}{l}\text { 4. Seseorang yang } \\
\text { ditakuti yang } \\
\text { dipilih. }\end{array}$ & $\begin{array}{l}\text { 4. Seseorang yang } \\
\text { dipilih sesuai } \\
\text { dengan hati } \\
\text { nurani pemilih } \\
\text { yang } \\
\text { diutamakan. }\end{array}$ \\
\hline
\end{tabular}

\section{Pustaka}

A Nizami, Sistem TI Pilkada untuk

Mencegah Keributan Pilkada,

Posted on Januari 25, 2008

(Internet)

Bambang Sudibyo, Pendidikan Bermutu

Untuk Semua, Kedaulatan

Rakyat, Edisi: 24 Mei 2007,

Yogyakarta

Ferniawan, Kisruh Pemilu 2009, 16 April

2009

(Internet)

http://www.henlia.com.2006/In

ternet),Empat Kualitas yang

Diperlukan untuk Menjadi
Seorang Pemimpin yang

Handal

H.Wiyono, Evaluasi Belajar, 1986,

Yogyakarta

Mendikbud, Kapita Selekta Implementasi

Kurikulum 2013, Badan

Pengembangan Sumber Daya

Manusia Pendidikan dan

Kebudayaan dan Penjaminan

Mutu Pendidikan Kementerian

Pendidikan dan Kebudayaan,

Jakarta , 2013

Muhammad Najib, Awasi Pemilu, Bentuk

Partisipasi Warga, Kedaulatan

Rakyat, Edisi: 16 November 2013

Sidarto Danusubroto, Demokrasi

Indonesia Demokrasi Wani

Piro, Kedaulatan Rakyat, Edisi:

24 November 2013

Suyanto, Pendidikan Masyarakat, Kedaulatan Rakyat, Edisi: 21

Mei 2009, Yogyakarta

Vincent P. Costa, Ed.D, Panduan

Pelatihan Untuk

Pengembangan Sekolah, 2000,

Jakarta

Widodo Ekatjahjana, Penyelesaian

Perselisihan Hasil Pemilukada

dalam Hukum Acara

Pemilukada di Indonesia,

2009 (Internet)

Zamroni, Panduan Managemen Sekolah,

Dikmenum, 2000, Jakarta 